\title{
Purification of Ligninase Isozymes from the White-Rot Fungus Trametes versicolor*
}

\author{
Leif Jönsson, Tomas Johansson, Kjell Sjöström and Per Olof Nyman \\ Division of Biochemistry, Chemical Center, University of Lund, P.O. Box 124, S-221 00 Lund, Sweden
}

\begin{abstract}
Jönsson, L., Johansson, T., Sjöström, K. and Nyman, P. O., 1987. Purification of Ligninase Isozymes from the White-Rot Fungus Trametes versicolor. - Acta Chem. Scand., Ser. B 41: 766-769.
\end{abstract}

In recent years great effort has been made to understand the pathways and mechanisms by which lignin is degraded in nature. Since lignin is one of the most common organic compounds found in nature, this is a reaction of considerable importance. It is also of interest in the areas of biotechnology and enzymology. The degradation of lignin is principally performed by filamentous fungi, primarily the white-rot basidiomycetes. Several different exoenzymes produced by these fungi are presumed to participate in the degradation of the complex lignin polymer.

The most studied species among the white-rot fungi is Phanerochaete chrysosporium and in 1983 this fungus was shown to produce the heme-containing exoenzyme ligninase (lignin peroxidase).$^{1,2}$ Ligninase : was recognized by an assay in which the enzyme was allowed to oxidize veratryl alcohol to veratraldehyde in the presence of hydrogen peroxide. ${ }^{3}$ The white-rot basidiomycete Trametes (Coriolus) versicolor is also able to degrade lignin. It is known to produce laccase, ${ }^{4}$ a copper-containing phenol oxidase thoroughly investigated by biophysical methods. ${ }^{5}$ Recently, it was shown to produce an enzyme similar to the ligninase from $P$. chrysosporium. ${ }^{6}$ Here, we describe the isolation of isozymes of this ligninase from $T$. versicolor.

\footnotetext{
${ }^{*}$ Communication at the Meeting of the Swedish Biochemical Society in Uppsala, August 21-22, 1987.
}

Table 1. Culture medium.

\begin{tabular}{ll}
\hline Compound & Concentration $/ \mathrm{g} \mathrm{I}^{-1}$ \\
\hline Glucose $\cdot \mathrm{H}_{2} \mathrm{O}$ & 2.20 \\
diammonium tartrate & 0.94 \\
$\mathrm{KH}_{2} \mathrm{PO}_{4}$ & 1.00 \\
$\mathrm{NaH}_{2} \mathrm{PO}_{4} \cdot 2 \mathrm{H}_{2} \mathrm{O}$ & 0.26 \\
$\mathrm{MgSO}_{4} \cdot 7 \mathrm{H}_{2} \mathrm{O}$ & 0.50 \\
$\mathrm{Thiamine}_{\mathrm{HCl}} \mathrm{HCl}$ & $1.00 \cdot 10^{-4}$ \\
$\mathrm{CaCl}_{2} \cdot 2 \mathrm{H}_{2} \mathrm{O}$ & $6.60 \cdot 10^{-3}$ \\
$\mathrm{FeSO}_{4} \cdot 7 \mathrm{H}_{2} \mathrm{O}$ & $5.00 \cdot 10^{-3}$ \\
$\mathrm{MnSO}_{4} \cdot \mathrm{H}_{2} \mathrm{O}$ & $3.79 \cdot 10^{-4}$ \\
$\mathrm{ZnSO}_{4} \cdot 7 \mathrm{H}_{2} \mathrm{O}$ & $5.00 \cdot 10^{-4}$ \\
$\mathrm{CuSO}_{4}$ & $6.40 \cdot 10^{-4}$ \\
Veratryl alcohol & 0.50 \\
\hline
\end{tabular}

\section{Materials and methods}

Chemicals. Reagent grade chemicals were used. Veratryl alcohol (3,4-dimethoxybenzyl alcohol, $96 \%$ ) was purchased from Janssen Chimica. Lhistidine monohydrochloride monohydrate (Merck) was used for preparing histidine buffers and the $\mathrm{pH}$ was adjusted with $\mathrm{NaOH}$.

Organism and culture conditions. $T$. versicolor (PRL 572) was grown at $25^{\circ} \mathrm{C}$ in stationary carbon-limited cultures. The medium used was that suggested by Dodson et al. ${ }^{6}$ with some modifications. The composition of the medium most often used is shown in Table 1. Veratryl alcohol was added to a final concentration of $3 \mathrm{mM}$ at the 
Table 2. An outline of the procedure used for purification of ligninase isozymes. All steps were carried out at $4^{\circ} \mathrm{C}$ (except the FPLC runs which were made at room temperature). Enzyme samples were filtered $(0.22 \mu \mathrm{m}$ Millipore filter) before application on the columns.

\begin{tabular}{ll}
\hline Step & Procedure \\
\hline 1 & $\begin{array}{l}\text { Filtration of culture fluid (0.22 } \mu \mathrm{m} \text { Millipore filter) and dialysis (first against distilled water and then } \\
\text { against buffer) }\end{array}$ \\
2 & Anion-exchange chromatography (Q-Sepharose, Pharmacia) \\
3 & Dialysis (against distilled water) and lyophilization \\
4 & Anion-exchange chromatography (Mono Q column, FPLC system, Pharmacia) \\
5 & Dialysis (first against distilled water and then against buffer) \\
6 & Chromatofocusing (Mono P column, FPLC system, Pharmacia) \\
7 & Dialysis (against distilled water) \\
\hline
\end{tabular}

time of inoculation. The $\mathrm{pH}$ was adjusted to 4.6. The inoculum was prepared by homogenizing a culture with glass beads. Erlenmeyer flasks (100$1000 \mathrm{ml}$ ) containing $30-300 \mathrm{ml}$ of culture medium were inoculated with $2 \%(v / v)$ of this suspension.

Enzyme assay. Ligninase was assayed essentially as described by Kirk et al. ${ }^{7}$ Reaction mixtures contained $0.1 \mathrm{M}$ sodium tartrate, $2 \mathrm{mM}$ veratryl alcohol and $0.4 \mathrm{mM} \mathrm{H}_{2} \mathrm{O}_{2}$. The reaction was monitored at room temperature (ca. $21^{\circ} \mathrm{C}$ ). One unit (U) of enzyme activity is defined as the amount of enzyme that will form $1 \mu \mathrm{mol}$ of veratraldehyde per min.
Electrophoresis. SDS-polyacrylamide gels (10 $20 \%, 1.5 \mathrm{~mm}$ thick) were used. ${ }^{8}$ The gels were stained with Coomassie brilliant blue R-250. For molecular weight determinations, gels were calibrated with phosphorylase b $(97400)$, bovine serum albumin (66000), ovalbumin (45000), carbonic anhydrase $(29000)$, soybean trypsin inhibitor (20100) and $\alpha$-lactalbumin (14200). Figures within parentheses are subunit molecular weights according to Sigma Chemical Co.

Purification. The purification of ligninase isozymes was carried out as outlined in Table 2 . After filtration $(0.22 \mu \mathrm{m})$ and dialysis [first

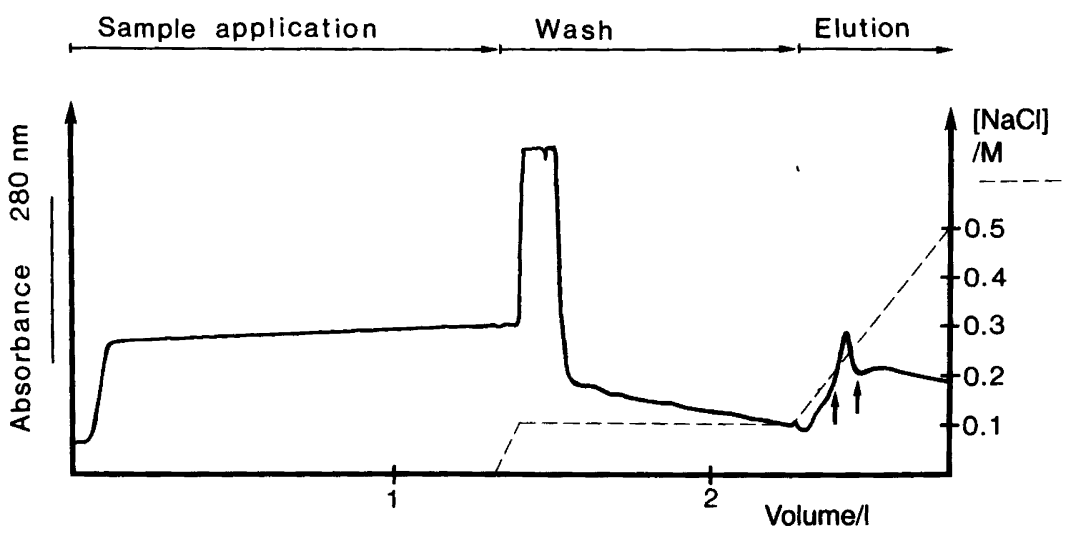

Fig. 1. Anion-exchange chromatography of ligninase-containing medium from cultures of $T$. versicolor on a Q-Sepharose column. Suitable fractions (between arrows) were pooled. They contained $87 \%$ of the initial activity $(48 \mathrm{U} / 55 \mathrm{U})$ in a volume of $5 \%$ of that applied to the column $(64 \mathrm{ml} / 1315 \mathrm{ml})$. The specific activity increased from 3 to $15 \mathrm{U}$ per $\mathrm{mg}$ of protein. For experimental details, see Materials and methods. 


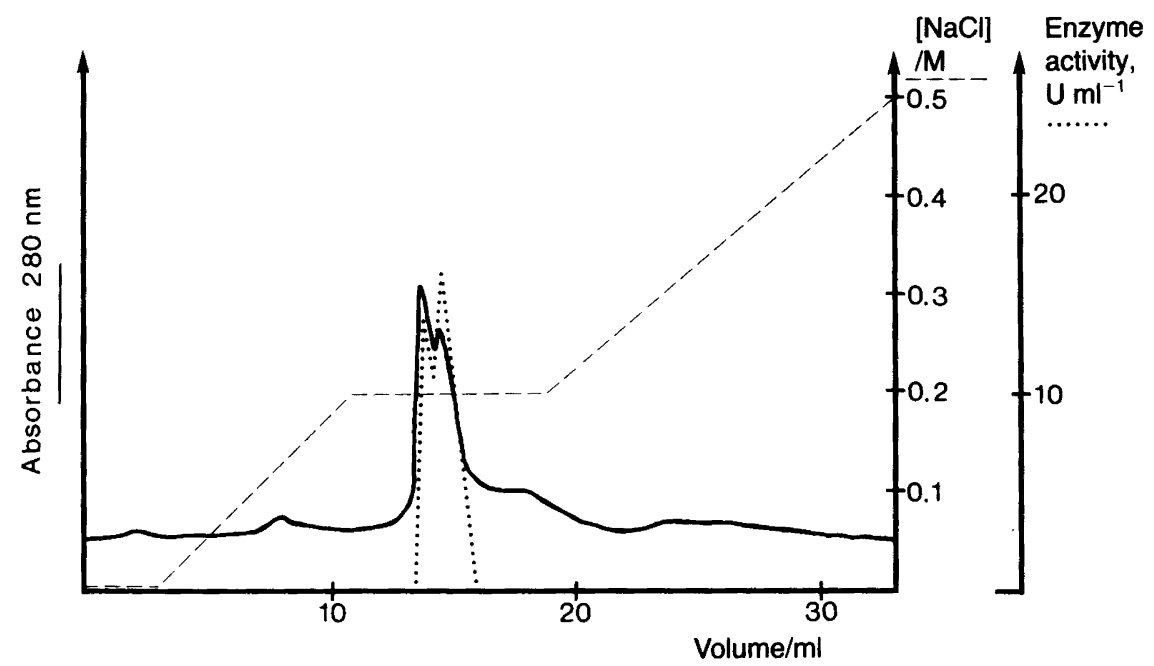

Fig. 2. Rechromatography of ligninase (from the chromatography corresponding to Fig. 1) on a Mono Q HR 5/5 anion-exchange column (FPLC system, Pharmacia). For experimental details, see Materials and methods.

against distilled water and then against $10 \mathrm{mM}$ histidine buffer ( $\mathrm{pH} \mathrm{5.3)]} \mathrm{the} \mathrm{culture} \mathrm{fluid} \mathrm{was}$ applied to a $50 \mathrm{ml}$ column $\left(9.5 \mathrm{~cm} \times 5.3 \mathrm{~cm}^{2}\right)$ of Q-Sepharose. The absorbance was measured at $280 \mathrm{~nm}$ with an LKB Uvicord S. The column was washed with $0.1 \mathrm{M} \mathrm{NaCl}+20 \mathrm{mM}$ histidine buffer, pH 5.3 (cf. Fig. 1, absorbance going off scale). The inclusion of $0.10 \mathrm{M} \mathrm{NaCl}$ when washing facilitated the elution of the main part of the protein material, while ligninase still adhered to the column. When the absorbance reached the baseline the enzyme was eluted with an $\mathrm{NaCl}$ gradient (Pharmacia gradient mixer GM-1) made from the following buffers:

\section{A: $250 \mathrm{ml}$ of $20 \mathrm{mM}$ histidine (pH 5.3) + $0.10 \mathrm{M} \mathrm{NaCl}$,}

B: $250 \mathrm{ml}$ of $20 \mathrm{mM}$ histidine (pH 5.3) + $0.50 \mathrm{M} \mathrm{NaCl}$.

Flow rate: $2.6 \mathrm{ml} \mathrm{min}{ }^{-1}$. Fraction volume: $4 \mathrm{ml}$. Protein concentrations were determined by the micro-Coomassie Blue procedure. ${ }^{9}$ After dialysis against water, the pooled fractions were lyophilized. Lyophilized enzyme was redissolved in $20 \mathrm{mM}$ histidine ( $\mathrm{pH} 6.0$ ) (about $3 \mathrm{ml}$ ), filtered $(0.22 \mu \mathrm{m})$ and subsequently applied to a Mono Q HR $5 / 5$ column [equilibrated with $20 \mathrm{mM}$ histidine ( $\mathrm{pH}$ 6.0)]. The enzyme was eluted with an
$\mathrm{NaCl}$ gradient (see Fig. 2) made from the following buffers:
A: $20 \mathrm{mM}$ histidine (pH 6.0),

B: $20 \mathrm{mM}$ histidine $(\mathrm{pH} \mathrm{6.0})+0.50 \mathrm{M} \mathrm{NaCl}$.

Flow rate: $0.5 \mathrm{ml} \mathrm{min}^{-1}$. Fraction volume: $0.5 \mathrm{ml}$. The fractions from the first and the second peak with ligninase activity were pooled separately.

Chromatofocusing was carried out on a Mono P HR 5/20 column. The column was equilibrated with $40 \mathrm{mM}$ start buffer (histidine). Flow rate: $1.0 \mathrm{ml} \mathrm{min}{ }^{-1}$. Eluent: $50 \mathrm{ml} 5 \%(v / v)$ Polybuffer 74 (Pharmacia). The gradients covered the region from $\mathrm{pH} 4.5$ to $\mathrm{pH} 3.1$.

\section{Results and discussion}

$T$. versicolor was found to produce ligninase under conditions similar to those described for $P$. chrysosporium, in accordance with previous observations. ${ }^{6}$ The addition of veratryl alcohol, which was made at the time of inoculation, stimulated ligninase activity. The amount of ligninase produced in the cultures could vary considerably, but in general a level of $50-100 \mathrm{U}^{-1}$ was obtained.

A purification scheme consisting of a series of 


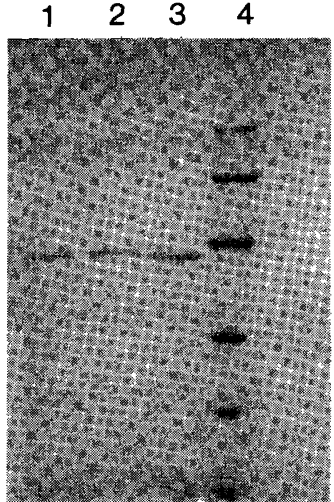

Fig. 3. Analysis of purified ligninase by SDS-PAGE. Lanes 1,2 and 3 show samples from three of the major peaks with ligninase activity obtained by chromatofocusing. The isozymes shown in lanes 1 and 2 were eluted at pH 3.4 and 3.2, respectively. The isozyme in lane 3 was eluted at a pH slightly below that for the isozyme in lane 1. Lane 4 shows the molecular weight standard.

chromatographic steps was developed. Several buffers were tested in the purification procedure but none of them proved to be more useful than histidine. Bis-tris ${ }^{8}$ was found to inhibit the assay reaction, and weaker inhibitory action was observed for several other buffer systems. The initial anion-exchange chromatography on Q-Sepharose (see Fig. 1) combines a significant purification with considerable concentration of the enzyme. In the subsequent anion-exchange chromatography on a Mono $Q$ column, the enzyme becomes divided into two peaks (see Fig. 2). The different isozymes can be further separated by chromatofocusing. In this way, three isozymes were obtained in substantial amounts and apparently in a state of high homogeneity (see Fig. 3). These isozymes were all eluted from the Mono $\mathrm{P}$ column at $\mathrm{pH}$ values between 3.4 and 3.2.

The molecular weights, obtained by SDSPAGE, ${ }^{*}$ range between 43000 and 45000 . The isozyme eluted from the Mono $\mathrm{P}$ column at pH 3.2 (lane 2 in Fig. 3) seems to have a slightly higher molecular weight than the other two. The

${ }^{\S} \mathrm{Bis}$ (2-hydroxyethyl)iminotris(hydroxymethyl)methane.

"Sodium dodecyl sulfate-polyacrylamide gel electrophoresis. molecular weights of the ligninase isozymes from $T$. versicolor determined here are lower than those reported by Dodson et al. ${ }^{6}$ and closer to the values given for ligninase from $P$. chrysosporium. For the latter enzyme, the molecular weight determined by SDS-PAGE was found to deviate significantly from the molecular weight of the amino acid sequence, probably due to glycosylation. ${ }^{10} \mathrm{~A}$ similar situation may exist for the isozymes from $T$. versicolor.

Besides the three major peaks obtained by chromatofocusing, several smaller peaks with capacity to oxidize veratryl alcohol were observed. This indicates the existence of additional forms of the enzyme.

The purification scheme outlined here has been devised in order to obtain isozyme fractions pure enough for detailed studies of molecular properties. Results obtained so far from analysis of amino-terminal ends by Edman degradation suggest that there are several structural genes for ligninase in $T$. versicolor.

Acknowledgements. We are grateful to Dr. Anna Maria Rosengren for providing FPLC facilities. This work was supported by a grant from Nils och Dorthi Troedssons forskningsfond.

\section{References}

1. Tien, M. and Kirk, T. K. Science 221 (1983) 661.

2. Glenn, J. K., Morgan, M. A., Mayfield, M. B., Kuwahara, M. and Gold, M. H. Biochem. Biophys. Res. Commun. 114 (1983) 1077.

3. Tien, M. and Kirk, T. K. Proc. Natl. Acad. Sci. U.S.A. 81 (1984) 2280.

4. Fåhraeus, G. and Reinhammar, B. Acta Chem. Scand. 21 (1967) 2367.

5. Reinhammar, B. and Malmström, B. G. In: Spiro, T. G., Ed., Metal Ions in Biology, Wiley, New York 1981, Vol. 3, p. 107.

6. Dodson, P.J., Evans, C.S., Harvey, P. J. and Palmer, J. M. FEMS Microbiol. Lett. 42 (1987) 17.

7. Kirk, T. K., Croan, S., Tien, M., Murtagh, K. E. and Farrell, R. L. Enzyme Microb. Technol. 8 (1986) 27.

8. Laemmli, U. K. Nature (London) 227 (1970) 680.

9. Bradford, M. M. Anal. Biochem. 72 (1976) 248.

10. Tien, M. and Tu, C.-P. D. Nature (London) 326 (1987) 520.

Received September 18, 1987. 